by Dr. Guppy crackled under his hands at night, and he could trace letters on its surface in phosphorescent hues with his finger-nail as he lay completely enveloped in its folds. The effects of these meteorological conditions soon showed themselves in the cessation of the action of the skin, in severe head. aches and sore-throat; in a tendency to palpitation and dyspnoea, and in sleeplessness, general lassitude and loss of appetite, most of which symptoms were attributed to the great lack of moisture in the air, for when a short spell of damp weather intervened, most of the unpleasant symptoms disappeared. An interesting phenomenon was observed every morning and evening. For about twenty minutes after sunrise and before sunset the shadow of the mountain was thrown back against the sky of the opposite horizon. It seemed as if some artist had been at work on the sky far away, and had painted in the profile of the mountain with a very uncanny blue.

Dr. Guppy's observations on the relative humidity have yet to be worked out, but he remarks that there was occasionally as much as a difference of $20^{\circ}$ between the wet and dry bulb thermometers, the usual difference being $10^{\circ}$ to $15^{\circ}$. The lowest temperature recorded at night was $15^{\circ} \mathrm{F}$, and the ninimun reading was usually below $20^{\circ}$. The average minimum temperature for the period, August 9 to 31 , was $23^{\circ} 5$. The highest temperature of the air in the shade was $61^{\circ} \cdot 2$, the average maximum daily being $53^{\circ} 6$, which places the average difference between the night and day temperature at $30^{\circ}$. This great daily range is about twice what it is at the coast.

\section{State of the Crater.}

In order to familiarise himself with the principal features of the crater, Dr. Guppy adopted the method of making a rough plan of it with a pocket prismatic compass. In some places the lava crust was thin and fragile, and although he never descended further than his waist, there was always in such localities a chance of a sudden descent into a cavern of considerable depth.

IHis descent into the crater was made on the north-west side. It was a tedious operation, and the loose boulders had to be trodden on very carefully, as they are often inclined to roll down and crush the intruder. As soon as Dr. Cuppy reached near the centre of the great pit the clouds began to pour in on all sides over the lips of the crater. In a few minutes he was enveloped in a dense mist, and any further observation was rendered impracticable. During the prevailing dry clear weather with a cloudless sky, "smoke" is only evident in two places in the crater, one near the centre and the other in the southwest corner from the base of a yellowish cliff, where there are apparently extensive deposits of sulphur. When, however, the sky is clouded, and especially when the air is moist, white vapour may be seen arising from the greater part of the surface of the crater. The change is a little startling, the true explanation being that a large amount of the vapour evolved is only visible in cloudy murky weather. It is, therefore. possible that the accuunts of two olsservers may vary greatly as to the crater's condition, and yet no difference in the con dition actually exist. This especially applies to the district on the south and south-west borders of the crater, stretching about a mile to the southward. In cloudy weather white vapour arises from many places in this area. In the bright clear weather that prevails the visitor may see nothing, and even walk unwitlingly over numerous cracks and fissures whence the invisible vapour is being discharged. Dr. Guppy took the temperature of several of these fissures. In those where the vapour was only seen in cloudy wetther the temperature was about $104^{\circ} \mathrm{F}$. When the "smoke" is always visible the temperature is far higher, $160^{\circ} \mathrm{F}$. and over. Many of these cracks and fissures exhibit evidence of having originally given passage to vapours at a very high temperature. The subterranean heat appears now more actively displayed in the district extending a mile to the south of the big crater than in the crater itself. A very large amount of vapour is discharged from the borders of a small crater lying near Pohaku Hanalei, and this is probably the smoke sometimes observed from the Kona coast. It is probable that the next eruption will occur on this, the south south-west slope of the mountain.

\section{Insect Life on the Summit.}

Curiously enough, insects of various descriptions are common on the summit. One species of butterfly common at the coast is not at all infrequent. The butterflies were more often to be found dead than alive, and those flying about were in a halfdrowsy condition and easily caught. There were flies of different kinds, the house-fly and the blue-bottle-fly proving a great nuisance. Besides these there were moths, bees, gnats, and an occasional dead dragon-fly; whilst bugs and other in. sects were collected as they fed upon the bodies of the dead butterflies. These insects were more common when the wind was southerly, and no doubt they had been brought up to this absolutely sterile region by the wind. Evidently most if not all of the butterfies and moths soon die, and probably the other in. sects too. The whole matter is, however, very suggestive, and shows how readily insects (even the parasitical bug) may find their way into the upper air-currents.

\section{PALESTINE EXPLORATION. ${ }^{1}$}

THE object of exploration is to obtain accurate knowledge of a country, its inhabitants, and its extant monuments and texts. That of Palestine has special interest to Christian races and to Jews, as serving to explain more clearly the sacred literature of their faith.

The results of such exploration may be judged by looking back a century to the time of Bayle, Voltaire and Astruc, when what was regarded as advanced scientific work assumed that the Hebrews were a savage race without literature, that history only began to be written about 500 B.C., and that the oldest civilisation was that of China and India. It is now known that the art of writing was practised in Egypt and Chaldea as early as 3000 B.c., that the Canaanites about the time of Joshua had a civilisation equal to that of surrounding nations, as had also the Hebrew kings; while, on the other hand, Chinese civilisation is only traceable to about 800 B. C., and that of India was derived from the later Persians, Arabs and Greeks. These results are due solely to exploration.

The requirements for exploration demand a knowledge not only of Syrian antiquities but of those of neighbouring nations. It is necessary to understand the scripts and languages in use, and to study the original records as well as the art and architecture of various ages and countries. Much of our information is derived from Egyptian and Assyrian records of conquest, as well as from the monuments of Palestine itself. As regards siripts, the earliest alphabetic texts date only from about 900 B.C., but previous to this period we have to deal with the cuneiform, the Egyptian, the Hittite and the Cypriote characters. The explorer must know the history of the cuneiform from $2700 \mathrm{~B} \mathrm{c}$. down to the Greek and Roman age, and the changes which occurred in the forms of some 550 characters originally hieroglyphics, but finally reduced to a rude alphabet by the Persians, and used not only in Babylonia and Assyria but also as early as 1500 B.C. in Asia Minor, Syria, Armenia, Palestine, and even by special scribes in Egypt. He should also be able to read the various Egyptian sciipts-the 400 hieroglyphics of the monuments, the hieratic, or running hand of the papyri, and the later demotic. The Hittite characters are quite distinct, and number at least 130 characters, used in Syria and Asia Minor from I500 B.C., or earlier, down to about 700 B.C. The study of these characters is in its infancy. The syllabary of Cyprus was a character derived from these Hitlite hieroglyphics, and used by the Greeks about 300 в.c. It includes some fifty characters, and was probably the original system whence the Phœnician alphabet was derived. As regards alphabets, the explorer must study the early Phœenician, and the Hebrew, Samaritan and Moabite, with the later Aramean branch of this alphabet, whence square Hebrew is derived. He must also know the Jonian alphabet, whence Greek and Roman characters arose, and the early Arab scripts-Palmyrene, Nabathean and Sabean, whence are derived. the Syriac, Cufic, Arabic and Himyaritic alphabets.

As regards languages, the scholars of the last century had to deal only with Hebrew, Aramaic, Syriac, Coptic and Greek, but as the result of exploration we now deal with the Ancient Egyptian whence Coptic is derived, and with various languages in cuneiform script, including the Akkadian (resembling pure Turkish) and the allied dialects of Susa, Media, Armenia and of the Hittites; the Assyrian, the earliest and most elaborate of Semitic languages; and Aryan tongues, such as the Persian, the Vannic and the Lycian.

The art and archilecture of Western Asia also furnishes much information as to religious ideas, customs, dress and history, including inscribed seals and amulets, early coins and gems. The explorer must also study the remains of Greek, Roman, Arab and Crusader periods, in order to distinguish these from the earlier remains of the Canaanites, Phœnicians, Hebrews, 1 A discourse at the Royal Institution by Lieut. Colonel C. R. Conder.

NO. 1462 , VOL. 57] 
Egyptians and Assyrians, as well as the art of the Jews and Gnostics about the Christian era, and the later pagan structures down to the fourth century A.D.

The monuments actually found in Palestine are few though important. The discovery at Tell el Amarna of about I5O letters written by Phonicians, Philistines and Amorites-and in one case by a Hittite prince--to the kings of Egypt, proves, however, the use of cuneiform on clay tablets by the Svrians as early as 1500 B.C., and one such letter has been recovered in the ruins of Lachish. The oldest monuments referring to Syria and Palestine are found at Tell Loh, on the Lower Euphrates, and date from 2700 B.c. Next to these are the Karnak lists of Thothmes III. about I600 B.C., recording the names of II9 towns in Palestine conquered after the defeat of the Hittites at Megiddo These lists show that the town names which occur in the Bible are mainly Canaanite and were not of Hebrew origin. The Canaanite language of this period was practically the same as the Assyrian, excepting that of the Hittites, which was akin to the Akkadian. In the next century the Tell el Amama tablets show that the Canaanites had walled cities, temples, chariots, and a. fully developed native art. They record the defeat of the Egyptians in the north by Hittites and Amorites, and the invasion of the south by the Abiri, in whom Drs. Zimmern and Winckler recognise the Hebrews, the period coinciding with the Old Testament date for Joshua's conquest.

An inscription of Mineptah, discovered in 1896, speaks of the Israelites as already inhabiting Palestine about I300 B.C., and agrees with the preceding. Other Egyptian records refer to the conquests of Rameses II. in Galilee and in Syria, when the Hittites retained their independence; and in the time of Rehoboam, Shishak has left a list of his conquests of $\mathrm{I} 33$ towns in Palestine, including the names of many towns noticed in the Bible.

The Hittite texts found at Hamalh, Carchemish and Merash, as well as in Asia Minor, belonged to temples, and accompany sculptures of religious origin. They are still imperfectly understood, but the character of the languages, the Mongol origin of the people, and the equality of their civilisation to that of their neighbours, have been established, while their history is recovered from Egyptian and Assyrian notices. The Amorites were a Semitic people akin to the Assyrians, and their language and civilisation are known from their own records, while they are represented at Karnak with Semitic features.

The oldest alphabetic text is that of the Moabite stone about 900 B.c. found at Dibon, east of the Dead Sea, on a pillar of basalt, and recording the victories of King Mesha over the Hebrews, as mentioned in the Bible. Several Bible towns are noticed, with the name of King Omri, and the language, though approaching Hebrew very closely, gives us a Moabite dialect akin in the Syrian, which is preserved in texts at Samalla,in the extreme north of Syria, dating from 800 B.C. The Phœnician inscriptions found at Jaffa, Acre, Tyre, Sidon, Gebal and in Cyprus do not date earlier than 600 B.C., and show us a distinct dialect less like Hebrew than the Moabite. The most important of these early texts is the Siloam inscription in the rock-cut aqueduct above the pool, found by a Jewish boy in 1880 . It refers only to the cutting of the aqueduct (in the time of Hezekiah), but it gives us the alphabet of the Hebrews and a language the same as that of Isaiah's contemporary writings. It is the only true Hebrew record yet found on monuments, and confirms the Old Testament account of IIezekiah's work.

The Assyrian records refer to the capture of Damascus by Tiglath Pileser III. in 732 B.C., and of Samaria in 722 B.C., as well as to Sennacherib's attack on Jerusalem in 702 B.C. The latter record witnesses also the civilisation of the Hebrews under IIezekiah, whose name occurs as well as those of Jehu, Azariah, Menahem, Ahaz, Pekah, and Hosea, who, with Manasseh, gave tribute to Assyrian kings.

About the Christian era Greek texts occur in Palestine, the most important being that of Herod's Temple at Jerusalem, forbildling strangers to enter, and those of Siah in Bashan, where also Herod erected a temple to a pagan deity. Such texts are very numerous in Decapolis, where a Greek population appears to have settled in the time of Christ.

The geographical results of exploration are also important for critical purposes. Out of about 500 towns in Palestine noticed in the Old Testament, 400 retain their ancient names, and about I 50 of these were unknown before the survey of the country in I872-82. The result of these discoveries has been to show that the topography of the Bible is accurate, and that the writers must have had an intimate knowledge of the land. Among the

$$
\text { NO. [462, VOL. } 57 \text { ] }
$$

most interesting Old Testament sites may be mentioned Lachish, Debir, Megiddo, Mahanaim, Gezer, and Adullam as newly identified; and of New Testament sites, Bethabara, Enon, and Sychar, all noticed in the fourth Gospel.

The existing Hebrew remains are few as compared with Roman, Arab, and Norman ruins of later ages. They include tombs, aqueducts, and fortress walls, with seals, weights, and coins. The most important are the walls of the outer court of Herod's great temple at Jerusalem, with his palace at Herodium, and buildings at Cæsarea and Samaria. The curious semi-Greek palace of Hyrcanus at Tyrus in Gilead dates from I 76 B.C. In Upper Galilee and east of Jordan there are many rude stone monuments-dolmens and standing stones--probably of Canaanite origin, as are the small bronze and pottery idols found in the ruins of Lachish. Sculptured bas-reliefs are, however, not found in Palestine proper, having been probably destroyed by the Hebrews.

This slight sketch may suffice to show the advance in knowledge due to exploration during the last thirty years. The result has been a great change in educated opinion as to the antiquity of civilisation among the Hebrews and Jews, and as to the historic reliability of the Bible records. Further exploration, especially by excavation, may be expected to produce yet more interesting results, and deserves general support, as all classes of thinkers agree in the desirability of increasing actual knowledge of the past. It is no longer possible to regard the Hebrews as an ignorant and savage people, or to consider their sacred writings as belonging necessarily to the later times of subjection under the Persians. Internal criticism is checked and controlled by the results of exploration, and by the recovery of independent historical notices.

\section{UNIVERSITY AND EDUCATIONAL INTELLIGENCE.}

CAMBridge. - The Walsingham Medal, given by the Lord High Steward, for original research in botany, geology, zoology, or physiology, is open to all graduates of the University under the standing of M.A. Monographs for the ensuing year are to be sent to Prof. Newton, Magdalene College, by October Io, 1898 .

An examination for the Sheepshanks Astronomical Exhibition will be held in Trinity College on November I9 and 20 . In addition to papers on astronomy, there will be an oral and practical examination at the Observatory. Candidates must be undergraduates, and, if successful, must become members of Trinity College.

Mr. G. H. A. Wilson, fifth wrangler 1895, has been elected to a fellowship at Clare College.

Prof. James M. Crafts, professor of organic chemistry in the Massachusetts Institute of Technology, will succeed the late General Francis A. Walker as the president of the Institute.

THE London Teihnical Education Gazette announces that a course on practical chemistry, dealing with the "manipulation of gases," will be conducted by Mr. M. W. Travers, at University College, on Fridays, at 5.30 p.m., commencing on Friday, November I2. This course will be of great value to those engaged in gas testing, and will deal with methods not hitherto published. A research course for teachers on "The effect of repeated heating on the magnetic permeability and electrical conductivity of iron and steel," is being conducted by Principal Tomlinson, F.R.S., at the South-west London Poly. technic, Manresa Road, Chelsea, on Saturday mornings from Io to I, with facilities for continuing experiments, if desired, from 2 to 5 . Teachers are admitted free; there are still a few vacant places in the class. Any teachers who wish to join should apply at once to Principal Tomlinson.

THE first volume of the Report of the United States Commissioner of Education, for the year I 895-96, has been received. Though largely concerned with elementary schools, the report contains several noteworthy articles on the higher branches of education. A detailed account is given of the Education Bill of 1896 , and the discussions which led to its withdrawal. Current statistics of education in Great Britain form the subject of a special chapter. Some of the features of the educational systems of Germany, Austria, and Switzerland are reported upon, the statistics which the report gives as to higher educa. tion in the German-speaking part of Europe being very valuable. It appears from the extensive tables contained in the 